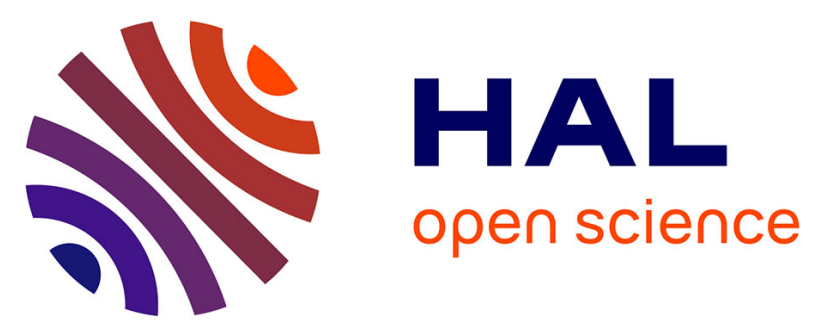

\title{
Building high-density peach linkage maps based on the ISPC 9K SNP chip for mapping mendelian traits and QTLS: benefits and drawbacks
}

Jehan-Baptiste Mauroux, Bénédicte Quilot-Turion, Thierry Pascal, Patrick Lambert, Michela Troggio, Ignazio Verde, Diego Micheletti, Maria José

Aranzana

\section{To cite this version:}

Jehan-Baptiste Mauroux, Bénédicte Quilot-Turion, Thierry Pascal, Patrick Lambert, Michela Troggio, et al.. Building high-density peach linkage maps based on the ISPC 9K SNP chip for mapping mendelian traits and QTLS: benefits and drawbacks. Acta Horticulturae, 2015, 1084, pp.113-118. 10.17660/ActaHortic.2015.1084.13 . hal-01349159

\author{
HAL Id: hal-01349159 \\ https://hal.science/hal-01349159
}

Submitted on 27 May 2020

HAL is a multi-disciplinary open access archive for the deposit and dissemination of scientific research documents, whether they are published or not. The documents may come from teaching and research institutions in France or abroad, or from public or private research centers.
L'archive ouverte pluridisciplinaire $\mathbf{H A L}$, est destinée au dépôt et à la diffusion de documents scientifiques de niveau recherche, publiés ou non, émanant des établissements d'enseignement et de recherche français ou étrangers, des laboratoires publics ou privés. 


\title{
BUILDING HIGH-DENSITY PEACH LINKAGE MAPS BASED ON THE ISPC 9K SNP CHIP FOR MAPPING MENDELIAN TRAITS AND QTLS: BENEFITS AND DRAWBACKS
}

\section{Authors:}

Keywords:

\author{
J.B. Mauroux, B. Quilot-Turion, T. Pascal , M. \\ Troggio , I. Verde, D. Micheletti , M.J. \\ Aranzana , P. Lambert \\ Prunus persica, Prunus davidiana, High- \\ Density genetic linkage map, SNP mapping, \\ $\mathrm{F}_{1}$ interspecific crosses, $\mathrm{F}_{2}$ intraspecific \\ crosses
}

DOI:

\begin{abstract}
:
"FruitBreedomics" European project has been designed by an international consortium including scientists, stakeholders and breeding companies. One of its aims is to increase the efficiency of breeding programs in apple (Malus $\times$ domestica) and peach (Prunus persica) by enabling Marker Assisted Breeding (MAB) using novel genomic tools. In the frame of this project, five peach mapping populations from the UGAFL (Unité de Génétique et Amélioration des Fruits et Légumes) peach breeding program (two intraspecific $\mathrm{F}_{2}$, two interspecific $\mathrm{F}_{1}$ derived from $P$. davidiana and one self-pollinated derived from 'Bolinha') segregating for mendelian traits and/or Quantitative Trait Loci (QTLs) for pest resistance and fruit quality were genotyped using the 9K SNP Illumina Infinium II Bead-chip delivered by the International Peach SNP Consortium (IPSC). Based on these data, genetic maps were then constructed; however mapping results were contrasted depending on the population considered. All maps aligned with the 8 pseudo-molecules of the Prunus persica Whole Genome sequence v1.0 (IPGI), but the best polymorphisms and coverage were obtained with the $F_{2}$ populations, for which twenty to twenty-nine percent of the SNPs were polymorphic covering 500 loci on average. However, these loci were unevenly distributed, although covering most of the peach genome. In contrast, for the F1 populations, only $5 \%$ of the SNPs were polymorphic in $P$. davidiana and the selfing of 'Bolinha' resulting in low coverage and very heterogeneous distributions. As primary consequence, this demonstrates the poor transferability of such a tool between species, even tightly related, and additionally highlights the relatively low efficiency of SNPs in term of useful polymorphism when parents belong to close peach germplasms. Consequently, regions containing QTLs and major genes could be insufficiently covered and need additional SNP development for MAB. The relevancy of using general medium-range SNP bead-chips for breeding purposes is discussed in this study.
\end{abstract}

